\title{
TARTU RADIOCARBON DATES IV
}

\section{E. ILVES, J.-M. PUNNING, and A. LIIVA}

Institute of Zoology and Botany, Academy of Sciences, Estonian SSR

The following list includes $\mathrm{C}^{14}$ dates and deals with the results of the methodological investigations carried out at the Geobiochemical Laboratory of the Institute of Zoology and Botany of the Academy of Sciences of the Estonian SSR in 1967-1968.

Wood dating from A.D. $1850 \pm 10 \mathrm{yr}$ has been used as a contemporary reference standard of modern carbon. All radiocarbon dates were calculated with the half-life of $\mathrm{C}^{14}$ being equal to $5568 \pm 30 \mathrm{yr}$. All dates have been calculated from the year 1950 .

In recent years several dating laboratories working by the scintillation method have been using solid catalysts for the trimerization of acetylene in benzene (Clark et al., 1959; Noakes, 1965; Pietig and Scharpenseel, 1966). In our laboratory we have applied the alumosilicatevanadium catalyst suggested by Arslanov and Gromova (1967). Tempered at $500^{\circ} \mathrm{C}$, the granulated alumosilicate carrier was treated in vacuum with a solution containing $90 \mathrm{~g}$ of $\mathrm{V}_{2} \mathrm{O}_{5}$ and $270 \mathrm{~g}$ of $(\mathrm{COOH})_{2} \cdot 2 \mathrm{H}_{2} \mathrm{O}$ in 0.51 of distilled water for $1 \mathrm{~kg}$ of the carrier. After washing with distilled water, drying and tempering at $500^{\circ} \mathrm{C}$ the catalyst is ready for use. The absorption rate of $\mathrm{C}_{2} \mathrm{H}_{2}$ on the catalyst $(50 \mathrm{~g}$ of the catalyst and 121 of $\mathrm{C}_{2} \mathrm{H}_{2}$ ) is 61 per hour. The benzene yield (calculated on the basis of $\mathrm{C}_{2} \mathrm{H}_{2}$ ) is 92 to $98 \%$.

The synthesis of carbide from carbonaceous samples is performed by the Barker method (1953) according to the formula:

$$
2 \mathrm{CO}_{2}+10 \mathrm{Li} \stackrel{660^{\circ} \mathrm{C}}{\longrightarrow} \mathrm{C}_{2} \mathrm{H}_{2}+4 \mathrm{Li}_{2} \mathrm{O}
$$

When the molar ratio of $\mathrm{CO}_{2}$ : Li equals 1:10, the $\mathrm{C}_{2} \mathrm{H}_{2}$ yield (on the basis of $\mathrm{CO}_{2}$ ) accounts for $92 \%$.

An additional one-channel scintillation device has been assembled and adjusted (Ilves, 1969). With $25 \mathrm{ml}$ of benzene, the pure count of modern carbon has been $147.96 \pm 0.23 \mathrm{cpm}$, the rate of the background was $8.31 \pm 0.054 \mathrm{cpm}$, the maximum determinable age being $49,800 \mathrm{yr}$ (48 hrs counting, $4 \sigma$ criterion).

\section{Kalina series}

\section{GEOLOGIC SAMPLES}

Kalina peat bog is located in NE Estonia, $14 \mathrm{~km} \mathrm{SW}$ of town Jõhvi. Samples from vertical wall of prospecting shaft dug $1 \mathrm{~m}$ from drainage channel crossing $S$ part of bog (Ilves, E. and Sarv, A., 1969, Stratigraphy and chronology of lake and bog deposits of Kalina Peat Bog: ENSV TA Toimetised, Keemia, Geoloogia, v. 18, no. 4, in press, in Russian). Coll. 1966 and subm. by E. Ilves and A. Sarv, Inst. Geol. Pollen analyses by A. Sarv. The Holocene is subdivided into pollen zones 


\section{TABle 1}

Kalina peat bog, stratigraphy of section

\begin{tabular}{|c|c|c|}
\hline Depth $(\mathrm{cm})$ & Sediment type & $\begin{array}{c}\text { Degree of } \\
\text { decomposition } \\
\text { (humification \%) }\end{array}$ \\
\hline to 15 & Sphagnum fuscum peat & 30 \\
\hline 15 to 110 & Eriophorum and Sphagnum peat & 35 to 45 \\
\hline 110 to 195 & Sphagnum fuscum peat & 25 \\
\hline 195 to 200 & pine and Sphagnum peat & 30 \\
\hline 200 to 205 & Eriophorum and wood peat & 30 \\
\hline 205 to 230 & wood and reed peat & 35 \\
\hline 230 to 235 & Sphagnum peat & 35 \\
\hline 235 to 240 & reed and Sphagnum peat & 30 to 35 \\
\hline 240 to 250 & wood and reed peat & 30 to 35 \\
\hline 250 to 265 & reed peat & 25 to 30 \\
\hline 265 to 270 & Bryales and reed peat & 25 \\
\hline 270 to 275 & peat sapropel & \\
\hline 275 to 290 & brown sapropel, compact & \\
\hline $\begin{array}{l}290 \text { to } 302 \\
302+\end{array}$ & olive-green sapropel containing aleurite & \\
\hline & & \\
\hline
\end{tabular}

according to T. Nilsson system (1961). Botanical analyses by H. and J. Allikvee.

\section{TA-143. Kalina}

Eriophorum and Sphagnum peat at depth 55 to $60 \mathrm{~cm}$. Contact between Pollen Zones $\mathrm{SA}_{1}$ and $\mathrm{SA}_{2}$.

\section{TA-155. Kalina}

Eriophorum and Sphagnum peat at depth 75 to $80 \mathrm{~cm}$. Contact between Pollen Zones $\mathrm{SB}_{2}$ and $\mathrm{SA}_{1}$ (Sub-Boreal-Sub-Atlantic contact).

\section{TA-144. Kalina}

$$
3520 \pm 65
$$$$
1570 \text { в.C. }
$$

Eriophorum and Sphagnum peat at depth 85 to $90 \mathrm{~cm}$. Pollen Zone $\mathrm{SB}_{2}$, maximum of spruce.

TA-145. Kalina

$$
3595 \pm 65
$$

1645 B.C.

Eriophorum and Sphagnum peat at depth 95 to $100 \mathrm{~cm}$. Contact between Pollen Zones $\mathrm{SB}_{1}$ and $\mathrm{SB}_{2}$.

TA-146. Kalina

$4660 \pm 95$

2710 B.C.

Sphagnum fuscum peat at depth 135 to $140 \mathrm{~cm}$. Pollen Zone $\mathrm{SB}_{1}$. 
TA-147. Kalina

$4805 \pm 65$

2855 в.c.

Sphagnum fuscum peat at depth 145 to $150 \mathrm{~cm}$. Pollen Zone $\mathrm{SB}_{1}$.

TA-148. Kalina

$4745 \pm 95$

2795 B.c.

Sphagnum fuscum peat at depth 155 to $160 \mathrm{~cm}$. Contact between Pollen Zones $\mathrm{AT}_{2}$ and $\mathrm{SB}_{1}$ (Atlantic-Sub-Boreal contact).

\section{TA-149. Kalina}

$5395 \pm 70$

3445 в.c.

Sphagnum peat with arboreal remains at depth 195 to $200 \mathrm{~cm}$. Pollen Zone $\mathrm{AT}_{2}$, rational boundary of spruce pollen.

\section{TA-150. Kalina}

$6410 \pm 70$ empirical boundary of spruce and oak pollen.

TA-151. Kalina

$7480 \pm 190$

$\mathbf{5 5 3 0}$ в.c.

Bryales and wood peat at depth 265 to $270 \mathrm{~cm}$. Pollen Zone $\mathrm{AT}_{1}$, maximum of walnut.

\section{TA-152. Kalina}

$8040 \pm 75$ Pollen Zones $\mathrm{BO}_{2}$ and $\mathrm{AT}_{1}$ (Boreal-Atlantic contact).

\section{TA-153. Kalina}

$9130 \pm 135$

Olive-green sapropel containing aleurite at depth 293 to $296 \mathrm{~cm}$. Contact between Pollen Zones $\mathrm{PB}$ and $\mathrm{BO}_{1}$ (Pre-Boreal and Boreal contact).

\section{Ulila series}

Ulila peat bog lies in depression of Lake Võrtsjärv. Samples from wall of prospecting shaft dug ca. $1 \mathrm{~km} \mathrm{~N}$ of settlement Ulila (Tartu Dist., Estonian SSR).

Samples coll. 1965 and subm. by E. Ilves. Pollen analyses by A. Sarv, botanical analyses by U. Valk, Silvicultural Research Lab., Ministry of Forest Management and Conservation of Estonian SSR.

TA-164. Ulila

$$
515 \pm 60
$$

Reed and Sphagnum peat at depth 25 to $30 \mathrm{~cm}$. Pollen Zone $\mathrm{SA}_{2}$.

TA-201. Ulila

$$
1740 \pm 70
$$

Reed and Sphagnum peat at depth 55 to $60 \mathrm{~cm}$. Pollen Zone $\mathrm{SA}_{1}$. 
TABLE 2

Ulila peat bog, stratigraphy of section

\begin{tabular}{|c|c|c|}
\hline Depth $(\mathrm{cm})$ & Sediment type & $\begin{array}{c}\text { Degree of } \\
\text { decomposition } \\
\text { (humification } \% \text { ) }\end{array}$ \\
\hline to 30 & wood peat & 40 to 50 \\
\hline 30 to 70 & reed and Sphagnum peat & 25 to 35 \\
\hline 70 to 100 & wood and reed peat & 35 to 40 \\
\hline 100 to 270 & reed peat & 25 to 35 \\
\hline 270 to 285 & $\begin{array}{l}\text { calcareous sapropel with } \\
\text { admixture of reed peat }\end{array}$ & \\
\hline 285 to 315 & lacustrine lime & \\
\hline 315 to 490 & $\begin{array}{l}\text { clay containing lacustrine } \\
\text { lime in top part }\end{array}$ & \\
\hline $490+$ & sand & \\
\hline
\end{tabular}

TA-110. Ulila

Wood and reed peat at depth 70 to $75 \mathrm{~cm}$. Pollen Zone $\mathrm{SA}_{1}$.

TA-111. Ulila

Wood and Sphagnum peat at depth 90 to $95 \mathrm{~cm}$. Pollen Zone $\mathrm{SB}_{2}$, maximum of spruce.

TA-112. Ulila

$4635 \pm 90$

Reed peat at depth 125 to $130 \mathrm{~cm}$. Pollen Zone $\mathrm{SB}_{1}$.

TA-113. Ulila

2685 B.C. $\mathrm{AT}_{2}$ and $\mathrm{SB}_{1}$ (Atlantic and Sub-Boreal contact).

TA-114. Ulila

$4905 \pm 70$

2955 B.c.

Reed peat at depth 170 to $175 \mathrm{~cm}$. Pollen Zone $\mathrm{AT}_{2}$.

TA-115. Ulila

$5260 \pm 70$

3310 в.c.

Reed peat at depth 180 to $185 \mathrm{~cm}$. Pollen Zone $\mathrm{AT}_{2}$.

TA-116. Ulila

$5460 \pm 70$ 3510 в.c.

$5580 \pm 70$ 3630 в.c.

Reed peat at depth 195 to $200 \mathrm{~cm}$. Pollen Zone $\mathrm{AT}_{2}$, rational bounclary of spruce pollen.

TA-117. Ulila

Reed peat at depth 205 to $210 \mathrm{~cm}$. Pollen Zone $\mathrm{AT}_{2}$, maximum of lime pollen and accumulation curve of broad-leaved species. 
TA-118. Ulila

$6315 \pm 70$

4365 в.C.

Reed peat at depth 215 to $220 \mathrm{~cm}$. Pollen Zone $\mathrm{AT}_{1}$.

TA-119. Ulila

$6580 \pm 90$

4630 в.C.

Reed peat coll. at depth $255 \mathrm{~cm}$ to $260 \mathrm{~cm}$. Pollen Zone $\mathrm{AT}_{1}$, maximum of elm and walnut.

TA-120. Ulila

$6915 \pm 70$

4965 B.c.

Calcareous sapropel with admixture of peat at depth 280 to 285 $\mathrm{cm}$. Pollen Zone $\mathrm{AT}_{1}$, empirical boundary of spruce pollen.

\section{Orgita series}

Orgita peat bog is in NW part of Estonian SSR, $4 \mathrm{~km} \mathrm{NE}$ of settlement Märjamaa. Samples from vertical wall of prospecting shaft dug $1.5 \mathrm{~m}$ from drainage channel.

\section{TABLE 3}

Orgita peat bog, stratigraphy of section

\begin{tabular}{clc}
\hline Depth $(\mathrm{cm})$ & \multicolumn{1}{c}{ Sediment type } & $\begin{array}{c}\text { Degree of } \\
\text { decomposition }\end{array}$ \\
\hline to 140 & $\begin{array}{l}\text { Sphagnum peat } \\
\text { Sphagnum peat containing } \\
\text { Eriophorum (particularly in } \\
\text { lower part) }\end{array}$ & $\begin{array}{l}\text { little-decomposed } \\
\text { to } 240\end{array}$ \\
240 to 245 & $\begin{array}{l}\text { Sphagnum peat } \\
\text { Eriophorum and Sphagnum peat }\end{array}$ \\
245 to 252 & wood and Sphagnum peat \\
252 to 260 & sedge peat containing wood \\
260 to 270 & Bryales and sedge peat \\
270 to 280 & Bryales and sedge peat \\
280 to 295 & containing wood \\
295 to 310 & $\begin{array}{l}\text { wood peat } \\
\text { moraine containing organics }\end{array}$ \\
310 to 317 & moraine
\end{tabular}

Samples coll. 1967 and subm. by E. Ilves and A. Sarv. Pollen analyses by A. Sarv.

TA-226. Orgita

Sphagnum peat at depth 150 to $155 \mathrm{~cm}$. Contact between Pollen Zones $\mathrm{SA}_{1}$ and $\mathrm{SA}_{2}$.

\section{TA-227. Orgita}

$1470 \pm 70$

Sphagnum peat at depth 215 to $220 \mathrm{~cm}$. Pollen Zone SA . 
TA-228 A. Orgita

Sedge peat at depth 260 to $265 \mathrm{~cm}$. Pollen Zone $\mathrm{SA}_{1}$. Comment: sample contained fragments of carabid beetles Pterosctichus sp., Agonum cf. ericeti (Panz.), and Agonum cf. mülleri (Hbst.); and of dytiscid beetles, Ilybius sp. Determinations were carried out by Prof. H. Haberman.

\section{TA-228 B. Orgita}

$2000 \pm 70$

Wood (pine) coll. at depth 260 to $265 \mathrm{~cm}$. Pollen Zone $\mathrm{SA}_{1}$.

\section{TA-229. Orgita}

$2620 \pm 75$ Zones $\mathrm{SB}_{2}$ and $\mathrm{SA}_{1}$. (Sub-Boreal-Sub-Atlantic contact).

\section{TA-230. Orgita}

670 B.C.

Wood peat at depth 300 to $205 \mathrm{~cm}$. Pollen Zone $\mathrm{SB}_{2}$.

$3815 \pm 70$ 1865 B.c.

\section{TA-178. Vesiku}

$6350 \pm 80$

4400 в.c.

Reed peat on right bank of R. Vesiku (I. Saaremaa). Peat layer, $30 \mathrm{~cm}$ thick, underlies coastal sands and gravel of Littorina Sea. Organogenous layer is underlain by lacustrine clayey marl. Sample coll. at depth 0 to $3 \mathrm{~cm}$ (from top of organogenous layer). Pollen analysis by $\mathrm{H}$. Kessel, Inst. Geol. Sample is referred to Pollen Zone VII (after von Post and Nilsson). Coll. 1966 and subm. by J.-M. Punning.

TA-179. Vesiku

$7960 \pm 80$

6010 B.c.

Sample from same complex as TA-178 at depth 33 to $36 \mathrm{~cm}$ from top of organogenous layer. Sample is assigned to Pollen Zone VII (after von Post and Nilsson).

\section{Gorelovo series}

Profile Gorelovo is situated in SW suburb of Leningrad. Description of this dist. is given in monograph by K. Markov (1931). Recent geomorphologic and palynologic investigations carried out in this dist. and a number of $\mathrm{C}^{14}$ datings indicate that organogenous materials accumulated in early Holocene and were later probably submerged under river deposits (Serebryanny and Punning, 1969).

TA-184. Gorelovo

$9470 \pm 120$

Peat at depth 110 to $112 \mathrm{~cm}$. 7520 в.с.

\section{TA-185. Gorelovo}

$9740 \pm 80$

Peat at depth 112 to $114 \mathrm{~cm}$. 


\section{TA-186. Gorelovo}

$10,010 \pm 120$

Peat at depth 114 to $116 \mathrm{~cm}$.

8060 B.C.

\section{TA-187. Gorelovo}

$10,070 \pm 130$

Peat at depth 120 to $122 \mathrm{~cm}$.

\section{Märkys and Ula series}

In many places along R. Märkys and its left tributary R. Ula in SE Lithuania, one can observe among sands dark-colored organogenous layers of interstadial character. These sediments contain aleurites, sapropels, peat, sometimes accumulations of considerable woody remains (Pinus silvestris L.). Shells of subfossil mollusks have been found in all profiles.

\section{TA-188. Mančiagire}

$11,630 \pm 120$ 9680 в.c.

Fragment of tree trunk from left bank of R. Ula, ca. $7 \mathrm{~km}$ below Mančiagire. Tree trunk is embedded in layer of dark-gray aleurite peat overlain by sands $16 \mathrm{~m}$ thick. Limonitized sands underlie organogenous layer. Coll. 1967 and subm. by J.-M. Punning and P. Vaitiekunas, Vilnius State Univ. Comment: $\mathrm{C}^{14}$ dating by Inst. Geol., Acad. Sci., Lithuanian SSR put putative age of sample at $17,340 \pm 840 \mathrm{yr}$ (Shulia et al., 1967).

\section{TA-240. Mančiagire}

$11,930 \pm 110$

Moss peat from same layer as TA-188.

9980 B.C.

TA-189. Pauosupe

$8790 \pm 90$

6840 в.C.

Tree trunk from right bank of $\mathrm{R}$. Uosupe near village Pauosupe. Sample is interbedded in fine- and medium-grained sands at depth 650 to 660. Coll. 1967 and subm. by J.-M. Punning.

\section{TA-190. Rudnja}

$11,530 \pm 120$

9580 в.c.

Tree trunk on right bank of $\mathrm{R}$. Ula near village Rudnja. Wood and peat lie interbedded in complexes of horizontal layers of sand. Overlying layer is $9 \mathrm{~m}$ thick, ca. $2 \mathrm{~m}$ back from edge of water. Check sample was taken from same trunk. Coll. 1967 and subm. by J.-M. Punning and P. Vaitiekunas. Comment: datings by Uppsala $\mathrm{C}^{14}$ Lab. are as follows:

$$
\begin{array}{lll}
\text { U-2107: } & 12,080 & +460 \\
\text { U-675: } & 11,970 & \pm 180 \\
\text { (Olsson, written commun.) }
\end{array}
$$

\section{TA-191. Zervynos}

Peat on left bank of R. Ula near village Zervynos, from prospecting shaft $5 \mathrm{~m}$ from place of contact of floodland with lower slope of left bank of R. Ula. Coll. 1967 and subm. by J.-M. Punning and P. Vaitiekunas. Comment: absolute ages of samples TA-124 and TA-125 from 
same profile had been previously dated at $11,930 \pm 110$ and $12,160 \pm$ 120, respectively (Radiocarbon, 1968, v. 10, p. 128-129).

\section{TA-192 A. Pamärkes}

$11,730 \pm 110$

9780 B.c.

Wood on right bank of $\mathrm{R}$. Märkis near village Pamärkes. Lake and bog deposits are included in sand beds. Coll. 1967 and subm. by J.-M. Punning and P. Vaitiekunas. Age of sample was determined by lignin fraction.

TA-192 B. Pamärkes

$11,820 \pm 110$

Same piece of wood as TA-192 A, but its age was determined by cellulose fraction.

\section{TA-195. Ohtla}

$8560 \pm 110$

Brown wood peat $\mathrm{N}$ of town Keila (N Fstonia), $17 \mathrm{~cm}$ thick, lain by deposits of Littorina Sea and clayey-aleuritic interbed of transgression of Lake Ancylus. Coll. 1967 by S. Püvi, Geol. Board; subm. by H. Stumbur, Geol. Board.

\section{TA-196. Sosnovy Bor}

$8060 \pm 70$

Wood fragments on left bank of R. Kovash (central part of Lenin grad Region) at depth $10.4 \mathrm{~m}$. Sands overlying peat and arboreal remains are characterized by Atlantic pollen spectrum and salt-water diatomaceous flora. Accumulation of peat started after regression of Ancylus Lakc. Coll. 1967 and subm. by L. Serebryanny, Inst. Geog., Acad. Sci., USSR.

\section{TA-197. Molodyozhnoye}

Wood fragments on left bank of $\mathrm{R}$. Chornaya W of town 7elenog.c. NW part of Leningrad Region. Sample lies at depth $205 \mathrm{~cm}$ in lower part of organogenous complex buried under beach barrier of Littorina Sea. Coll. 1967 and subm. by L. Serebryanny. On basis of pollen-analytic data L. Serebryanny attributed accumulation of organogenous layers to Pollen Zone VII (after von Post and Nilsson).

\section{TA-198. Järise}

$6960 \pm 70$

Organogenous deposits, 0 cm (W Estonia) torina Sea. Coll. 1967 and subm. by G. Eltermann, Geol. Board.

TA-199. Deseles Leinieki

$\geqslant 55,000$

Dark-brown hard sapropelite near village Deseles in basin of $\mathbf{R}$. Letize (SW Latvia). Sapropelite layer is embedded in moraines. Coll. 1966 and subm. by J.-M. Punning. Pollen-analytic investigations by $M$. Danilans (1966) assigned accumulation of lake and bog deposits to Likhvin (Mindel-Riss) Interglacial. Comment: at Vernadski Inst. of Geochem., sample had been dated $\geqslant 34,000 \mathrm{yr}$ (Vinogradov et al., 1966). 
TA-200. Gvildzai

Submorainic lake and bog deposits in valley of $\mathrm{R}$. Dange $\mathrm{N}$ of town Klaipeda (NW Lithuania). Sample coll. 1967 and subm. by P. Vaitiekunas and J.-M. Punning. Comment: accumulation of these deposits has been referred to Riss-Würm Interglacial (Woldstedt, 1955; Vaitiekunas, 1961), to Neo-Pleistocene (Gudelis, 1961; Vonsavičius, 1967), and to MindelRiss Interglacial (Kondratene, 1967).

\section{TA-194. Kunda}

$$
\begin{aligned}
& 11,690 \pm 150 \\
& 9740 \text { B.C. }
\end{aligned}
$$

Bryales moss near town Kunda ( $\mathrm{N}$ Estonia). Moss is contained in lacustrine marl and overlies varved clay and sand. Coll. 1967 and subm. by R. Pirrus, Inst. Geol., Acad. Sci., Estonian SSR.

\section{TA-193. Oara}

$$
6100 \pm 50
$$

4150 B.C.

Lagoon sapropel on beach of Bay of Pärnu, $6 \mathrm{~km} \mathrm{~N}$ of Audru (SW Estonia). Sample coll. in upper part $(0$ to $3 \mathrm{~cm})$ of organogenous layer whose total thickness amounts to $33 \mathrm{~cm}$. Lower and upper parts of this layer contain remains of salt-water diatomaceous algae. Coll. 1967 and subm. by J.-M. Punning. Pollen analysis performed by H. Kessel refers upper part of submerged deposits to Pollen Zone VI (after Post-Nilsson).

\section{TA-222. Dröstorp starr}

$$
\delta \mathbf{C}^{14}=616 \pm 10 \% \text { o }
$$

Plants (Carex elata) coll. 1966 in Sweden $\left(56^{\circ} 35^{\prime} \mathrm{N}\right.$ Lat, $16^{\circ} 33^{\prime}$ E Long). Coll. by L. K. Königsson, subm. by I. U. Olsson (Univ. of Uppsala). Sample was measured at Uppsala $\mathrm{C}^{14}$ laboratory as follows: $\mathrm{U}-51, \delta \mathrm{C}^{13}=-28.1 \%, \Delta=699.5 \pm 12.6 \%$, (Olsson, written commun.).

\section{TA-225. Kakra}

$9150 \pm 80$ 7200 B.c.

Well-preserved piece of wood (pine, ca. $4 \mathrm{~cm}$ diam. with 33 year-rings) from NE part of I. Kihnu, Pärnu Dist., SW Estonia. Sample coll. from $4.2 \mathrm{~m}$ deep prospecting shaft lying horizontally at depth $4 \mathrm{~m}$ (ca. $1 \mathrm{~m}$ above sea level) in fine-grained sand. Sample overlain by fine-grained sand $2.5 \mathrm{~m}$ thick, pebble and gravel $1 \mathrm{~m}$ thick, and eolian sand $0.5 \mathrm{~m}$ thick. Coll. 1967 and subm. by H. Sepp, Collective Farm "Soviet Partisan".

\section{TA-223. Naroch}

$$
10,330 \pm 100
$$

Wood remains (pine) from outcrop on $\mathrm{S}$ bank of $\mathrm{R}$. Näroch (Belorussian SSR). Coll. 1967 and subm. by L. N. Voznyachuk, Belorussian Lenin State Univ. See TA-134, TA-135, Radiocarbon, 1968, v. 10, p. 379.

\section{TA-239. Pühajoe}

$$
2850 \pm 130
$$

Wood remains from boring on left bank of R. Pühajồ (N Estonia). Remains are embedded in coarse-grained, little-graded sand containing gravel, pebble, and boulders. Subjacent to them lie deposits of Lower 
Cambrian system. Sample lay at depth $16 \mathrm{~m}$. Coll. 1968 and subm. by H. Erisalu (Geol. Board).

\section{TA-241. Nouni}

$10,900 \pm 110$

8950 B.c.

Plant remains picked from prospecting shaft near Lake Nõuni, Valga Dist., SE Estonia. Stratigraphy of sec.: gravel, $50 \mathrm{~cm}$; layered fine-grained sand, $50 \mathrm{~cm}$; layered medium-grained sand with aleurite interbeds, 25 $\mathrm{cm}$; aleurite fine-grained sand with plant and moss remains, $20 \mathrm{~cm}$; below bluish-gray coarse sand and gravel. Coll. 1968 and subm. by J.-M. Punning and R. Pirrus, Inst. of Geol.

$$
\text { II. ARCHAEOLOGIC SAMPLES }
$$

\section{TA-202. Usvyaty}

$4230 \pm 70$ 2280 B.c.

Wood from Neolithic settlement Usvyaty IV, Usvyaty Dist., Pskov Region, RSFSR on S outskirts of settlement Usvyaty in flood-land of $\mathrm{N}$ part of Lake Usvyaty. Sample coll. from lower horizon (IV) of cultural layer (B) at depth of $110 \mathrm{~cm}$ and represents $\log$ fragment lying horizontally with peg driven through it (Sample TA-203). Pollen-analytic data by E. Spiridonova attribute Layer B to 2nd half of Atlantic period. Presumed archaeologic age of Layer B: 2nd half of 3rd millennium or boundary of 3rd/2nd millennium B.c. Coll. 1966 and subm. by A. Miklayev, State Hermitage of USSR.

\section{TA-203. Usvyaty}

$4110 \pm 70$

Wood fragment of peg driven through log (Sample TA-202) coll. from Neolithic settlement Usvyaty IV. Top of peg $65 \mathrm{~cm}$, its end driven through $\log 130 \mathrm{~cm}$ deep. Coll. 1966 and subm. by A. Miklayev. Probable age of sample: 2nd half of 3rd millennium or boundary of $2 \mathrm{nd} / 3 \mathrm{rd}$ millennium B.c.

\section{TA-204. Lohavere}

\section{A.p. 1245}

$\mathbf{7 0 5} \pm \mathbf{7 0}$

Charcoal from NW part of wall of fortified stronghold Lõhavere, Viljandi Dist., Estonian SSR, $4 \mathrm{~km} \mathrm{E}$ of settlement Suure-Jaani. Depth of sample $72 \mathrm{~cm}$. Coll. 1960 by A. Liiva; subm. by Acad. H. Moora, Inst. of Hist., Acad. Sci., Estonian SSR. Putative age of sample: 1st half of 13 th century.

\section{TA-217. Padise}

$$
\text { A.D. } 1170
$$

$780 \pm 100$

Charcoal from $S$ part of $E$ wall of fortified stronghold Padise, Harju Dist., N Estonia. See TA-73, Radiocarbon, 1966, v. 8, p. 436. Depth of sample $225 \mathrm{~cm}$. Presumed archaeologic age: ca. 700 A.D. Coll. 1964 and subm. by O. Saadre, Inst. of Hist.

\section{TA-218. Medvezhya peshchera (cave)}

$8480 \pm 100$

6530 B.C.

Fragments of subfossil bones from Medvezhya peshchera (cave), Ust-Unyin village soviet, Troitsko-Pechorski Dist., Komi ASSR. Coll. 
1966 and subm. by I. Kuzmin, Inst. of Zool., Acad. Sci., USSR. Putative age: Late Pleistocene.

\section{TA-219. Tamula}

Wood from Burial 22 of Late Neolithic settlement Tamula, $0.5 \mathrm{~km}$ $\mathrm{S}$ of town Voru, SE Estonia. Sample coll. from under cultural layer at depth 58 to $77 \mathrm{~cm}$ and is referred to early stage of settlement. Coll. 1961 and subm. by L. Jaanits, Inst. of Hist. Presumable age: boundary of $3 \mathrm{rd} / 2 \mathrm{nd}$ millennium or early 2 nd millennium B.c.

\section{TA-221. Kaninskaya}

$1900 \pm 110$

\section{A.D. 50}

Fragment of subfossil bones from monastery Kaninskaya, Ust-Unyin, village soviet. Troitsko-Pechorski Dist., Komi ASSR. Coll. 1966 and subm. by I. Kuzmin. Putative age of sample: 2nd millennium B.C.

Date lists:
Tartu I
Tartu II
Tartu III
A. Liiva, E. Ilves, and J.-M. Punning, 1966
J.-M. Punning, E. Ilves, and A. Liiva, 1968

REFERENCES

Arslanov, H. A. and Gromova, L. I., 1967, Author's Certificate 1136238/23-4, Sept. 26, 1967.

Barker, H., 1953, Radiocarbon dating: large-scale preparation of acetylene from organic material: Nature, v. 172, p. 631-632.

Clark, A., Hogan, J. P., Witt, D. R., and Lanning, W. C., 1959, The polymerisation of acetylene and homologs: World. Petrol. Kongr. Proc. 5-th N.Y. (4).

Danilans, I., 1966, Pollen zones of Mindel-Riss deposits in the Basice of Letiza River and their correlation with analogens zones in other regions: Palynology in geological research of the Baltic areas, Riga.

Gudelis, V. K., 1961, Outline of geology and palcogeography of the Quaternary (Anthropogen), in: Lithuania: Inst. Geol., Prace, v. 34, Warsaw (in Russian).

Ilves, E., 1969, One-channel scintillation device for the determination of natural radiocarbon: ENSV TA Toimetised, Bioloogia, v. 18, no. 3 (in Russian).

Kondratene, O. P., 1967, On problematic intermorainic deposits at Purmalei and Gvildzai: Trudy Inst. Geol., V, Vilnius (in Russian).

Markov, K. K., 1931, Development of the relief of the northwestern part of Leningrad Region: Moscow-Leningrad (in Russian).

Nilsson, T., 1961, Ein neues Sta’ndardpollendiagramm aus Bjärsjöholmssjön in Schonen: Lunds Univ. Arsskrift, N.F. Avd. 2, v. 56, no. 18.

Noakes, J. E., 1965, Cataliste for production of benzene samples: Internatl. carbon-14 and tritium dating conference Proc., Pullmann, Washington.

Pietig, F. and Scharpenseel, H. W., 1966, Altersbestimmung mit dem FlüssigkeitsSzintillations-Spektrometer. Ein neuer Katalysator zur Benzolsynthese: Atompraxis, v. 12 , no. 2.

Sercbrryanny, L. R. and Punning, J.-M. K., 1969, Results of the radiochronometric and palynological study of buried peat in Gorelovo-Koierovo District near Leningrad, in: Holocene: Moscow (in Russian).

Shulia, K. S., Lujanas, V. J., Kibilda, M. K., and Genutene, I. K., 1967, Radiocarbon dating of the terraces of the River Ula, Lithuanian SSR, v. 175, no. I (in Russian).

Vaitiekunas, P. P., 1961, Structure and some questions of the stratigraphy of the Pleistocene deposits of the Lithuanian SSR: Dissertation abs. Vilnius (in Russian).

Vinogradov, A. P., Devirts, A. L., Dobkina, E. I., and Markova, N. G., 1966, Data of the Radiocarbon Laboratory of the Vernadski Institute of Geochemistry and Analytical Chemistry, in: Upper Pleistocene, Stratigraphy and Geochronology, Moscow (in Russian).

Vonsavicius, V. P., 1967, Structure of the Quaternary deposits of South-Western Baltic Territory: Trudy Instituta Geologii, V, Vilnius (in Russian).

Woldstedt, P., 1955, Norddeutschland und angrenzende Gebiete in Eiszeitalter, 2, Aufl.. Stuttgart. 